PENGARUH SUHU TUANG PADA KUALITAS GANTUNGAN KUNCI BERBAHAN BAKU PEWTER DENGAN METODE SPIN CASTING

\author{
The Effect of Pour Temperature on Quality of Pewter Key Chain Using Spin Casting \\ Method
}

Agung Eko Sucahyono ${ }^{1}$, Purnama Nugroho ${ }^{2}$, dan Risdiyono²

${ }^{1}$ Balai Besar Kerajinan dan Batik, Jl. Kusumanegara No.7 Yogyakarta, Indonesia

${ }^{2}$ Fakultas Teknologi Industri, Universitas Islam Indonesia

\section{Korenspondesi Penulis}

Email $\begin{array}{ll}\text { Naskah Masuk } & : 30 \text { Agustus } 2018 \\ \text { Revisi } & : 26 \text { November } 2018 \\ \text { Disetujui } & : 27 \text { November } 2018\end{array}$

Kata kunci: gantungan kunci, spin casting, karet silikon (RTV), suhu tuang

Keywords: keychain, spin casting, RTV silicon rubber, pour temperature

\begin{abstract}
ABSTRAK
Gantungan kunci adalah salah satu jenis suvenir yang paling diminati. Ada banyak metode yang digunakan dalam membuat suvenir gantungan kunci, namun teknik pengecoran dengan metode spin casting adalah metode yang tepat apabila digunakan untuk produksi secara massal. Spin casting dipilih karena prosesnya yang cepat. Dalam proses pengecoran spin casting, terdapat beberapa faktor yang mempengaruhi hasil produk pengecoran, salah satunya adalah suhu tuang cairan logam (pewter). Penelitian ini bertujuan untuk mengetahui pengaruh suhu tuang pada proses spin casting dalam pembuatan suvenir gantungan kunci terhadap detail bentuk gantungan kunci. Variasi suhu tuang yang digunakan adalah menggunakan tiga variasi suhu tuang (suhu rendah $160-171^{\circ} \mathrm{C}$, sedang $190-200^{\circ} \mathrm{C}$, dan tinggi $200-220^{\circ} \mathrm{C}$ ). Bahan cetakan yang digunakan adalah karet silikon Room Temperature Vulcanisation (RTV) 585 ditambah dengan talc. Dari hasil penelitian yang dilakukan, diketahui bahwa suhu tuang cairan pengisi berpengaruh terhadap hasil pengecoran, antara lain: (1) Untuk relief dengan ukuran yang kecil dan sempit, semakin tinggi suhu tuang cairan logam pengisi akan memiliki hasil yang lebih tajam, (2) semakin tinggi suhu tuang cairan logam pengisi membuat massa produk semakin besar.
\end{abstract}

\title{
ABSTRACT
}

Souvenirs are made of a variety of materials, one of which is pewter. One of pewter souvenir products is keychain. There are some methods used in making keychain souvenirs, but casting technique with spin casting method is the suitable method used for mass production. Spin casting was chosen because of its rapid process. In the process of spin casting, there are several factors that affect the results of casting products, one of which is the pour temperature of the metal cast (pewter). This study aims to determine the influence of pour temperature on the spin casting process in making souvenirs of keychain. The variations of pour temperature were low, medium and high temperature i.e. T1(160 $171^{\circ} \mathrm{C}, \mathrm{T2} 190-200^{\circ} \mathrm{C}$, and T3 $200-220^{\circ} \mathrm{C}$ ). The mold material used is silicone rubber Room Temperature Vulcanisation (RTV) 585 with talc. The results of research were: (1) for reliefs of small and narrow size, the higher the pour temperature of the filler metal liquid, the sharper the result, (2) the higher the temperature of the liquid metal pours filler, the bigger the mass of the product. It can be concluded that the liquid fill pour temperature affect the results of casting 


\section{PENDAHULUAN}

Indonesia merupakan salah satu penghasil timah di dunia. Hasil penambangan timah di Indonesia hampir 300.000 ton pertahun Namun sayangnya 95\% hasil timah ini diekspor keluar negeri karena pemanfaatan timah yang minim di dalam negeri. Salah satu industri yang memanfaatkan timah adalah industri kerajinan. Biasanya timah diubah dulu menjadi panduan sehingga terbentuklah pewter yang terdiri dari $91-97 \%$ timah dan sisanya merupakan gabungan tembaga dan perak. Salah satu daerah yang terkenal dalam pembuatan kerajinan pewter adalah Kabupaten Bangka Barat yang salah satu pembuatnya adalah Home Industry The Beauty Of Tin Craft Kota Muntok (Puji Widi Rahayu, 2013). Kerajinan pewter ini biasanya dibuat dengan menuangkan pewter cair ke dalam cetakan. Setelah dingin, pewter dikeluarkan dari cetakan dan dihaluskan. Karena proses penuangannya yang dilakukan dengan cara tradisional, maka hal yang sangat sering terjadi yaitu tingkat porositas produk yang cukup besar. Untuk menghadapai hal ini maka perlu dilakukan metode untuk meningkatkan kepadatan hasil cetakan, salah satunya dengan metode spin casting.

Teknologi spin casting adalah suatu proses penuangan dan pembekuan logam yang memiliki titik leleh rendah dalam satu cetakan menggunakan prinsip gaya sentrifugal. Gaya sentrifugal dari mesin spin casting akan mendorong lelehan logam untuk memenuhi setiap bagian detail permukaan di lubang cetakan (Balingit \& Maglaya, 2013).
Pada penelitian ini diharapkan akan didapatkan titik leleh yang optimal untuk digunakan pada mesin spin casting yang ada di Balai Besar Kerajinan dan Batik yang dapat meningkatkan kualitas produk gantungan kunci pewter. Kualitas ini dapat berupa kepadatan massa, kesesuaian dengan master cetakan dan keuletan logamnya. Analisa yang digunakan berupa perhitungan massa dan pengamatan visual.

\section{Spin Casting}

Spin casting merupakan salah satu dari beberapa metode proses pengecoran yang biasa digunakan dalam membuat barang yang sama dalam jumlah banyak. Pengecoran (casting) adalah salah satu teknik pembuatan produk dimana logam dicairkan pada tungku peleburan kemudian dituangkan baik dengan memanfaatkan gaya gravitasi atau gaya lain ke dalam rongga suatu cetakan yang serupa dengan bentuk asli dari produk cor yang akan dibuat. Prinsip dasar dari spin casting adalah dengan menggunakan gaya sentrifugal untuk pengecoran. Secara garis besar cara kerja dari spin casting adalah sebuah cetakan silicone rubberdiputar di sebuah mesin pemutar, kemudian logam yang telah dicairkan dimasukkan ke dalam cetakan tersebut. Dengan adanya gaya sentrifugal yang terjadi maka logam cair akan terlempar menjauhi titik pusat sehingga memenuhi setiap bagian detail permukaan di lubang cetakan dan menghasilkan produk yang diinginkan.

Ada banyak faktor yang mempengaruhi produk akhir dalam proses pengecoran spin. Beberapa faktor tersebut adalah 
temperatur cetakan, suhu bahan yang digunakan untuk pengecoran, kecepatan spin cetakan dan viskositas logam cair yang akan dicetak (Karpitschka, Weber, \& Riegler, 2015). Tingkat evaporasi bahan juga akan mempengaruhi keakuratan dari produk akhir (Danglad-Flores, Eickelmann, \& Riegler, 2018).

\section{Cetakan Karet (Rubber Mold)}

Cetakan adalah alat yang digunakan dalam industri manufaktur untuk membentuk berbagai macam jenis produk. Secara umum cetakan harus memiliki bagian-bagian utama sebagai berikut :

a. Cavity (rongga cetakan)

Merupakan ruangan tempat logam cair yang dituangkan kedalam cetakan. Bentuk rongga ini sama dengan benda kerja yang akan dicor. Rongga cetakan dibuat dengan menggunakan pola.

b. Core (inti)

Fungsinya adalah membuat rongga pada benda coran. Inti dibuat terpisah dengan cetakan dan dirakit pada saat cetakan akan digunakan.

c. Gating system (sistem saluran masuk) Merupakan saluran masuk ke rongga cetakan dari saluran turun. Gating system suatu cetakan dapat lebih dari satu, tergantung dengan ukuran rongga cetakan yang akan diisi oleh logam cair.

d. Sprue (saluran turun)

Merupakan saluran masuk dari luar dengan posisi vertikal. Saluran ini juga dapat lebih dari satu, tergantung kecepatan penuangan yang diinginkan.

e. Pouring basin
Merupakan lekukan pada cetakan yang fungsi utamanya adalah untuk mengurangi kecepatan logam cair masuk langsung dari lade/ke sprue. Kecepatan aliran logam yang tinggi dapat terjadi erosi pada sprue dan terbawanya kotoran-kotoran logam cair yang berasal dari tungku kerongga cetakan.

\section{f. Raiser (penambah)}

Merupakan cadangan logam cair yang berguna dalam mengisi kembali rongga cetakan bila terjadi penyusutan akibat solidifikasi.

Pada proses spin casting seringkali menggunakan silicone rubber sebagai bahan cetakannya. Keuntungan rubber mold yaitu dapat membuat cetakan dengan kerumitan produk yang tinggi. Keuntungan lain adalah sifat karet silikon yang memiliki daya kerja dan ketahanan korosi yang sangat baik, juga memiliki sifat kimia dan fisiologis yang stabil (Zheng et al., 2016).

Ada dua jenis karet yang biasa digunakan untuk cetakan karet :

\section{a. HTV (High Temperature Vulcanisation)}

HTV silikon disusun oleh rantai polimer silikon yang panjang dengan kelompok terminal grup vinyl, sebagai tambahan suatu agen ikatan silang diisi oleh fumed atau precipitated silica dan aditif lainnya untuk membuat sifat properti khusus. HTV juga mempunyai sifat sebagai insulator sehingga banyak digunakan menjadi insulator listrik pengganti porselen dan kaca (Buontempo et al., 2016).

b. RTV (Room Temperature Vulcanisation) 
Silikon ini terdiri dari silicone cair dan hardener. Untuk membuat silikon menjadi padat perlu ditambahkan catalyst/hardener dengan perbandingan tertentu untuk mendapatkan karet yang keras. Proses ini juga disebut sebagai room temperature vulcanized atau proses vulkanisasi dengan suhu ruang karena proses vulkanisasi dengan udara terbuka atau suhu kamar (Setiawan, 2010).

Vulkanisasi mempunyai arti yang sama dengan sambung-silang, pematangan secara khusus sama artinya dengan sambung-silang namun seringkali lebih kepada kombinasi dari polimerisasi adhesi dengan sambung-silang (Atha Illah \& Ardhyananta, 2013). RTV silikon juga sangat banyak digunakan dalam berbagai macam industri karena sifat mekanis dan elektrisnya yang baik (Kumar, Lee, \& Lee, 2016).

\section{Pewter}

Kandungan dalam logam pewter adalah 97\% timah putih ( $\mathrm{Sn}), 2 \%$ tembaga $(\mathrm{Cu})$, dan $1 \%$ antimon (Sb), dimana fungsi dari tembaga untuk mengkilapkan timah, sedangkan antimon berfungsi untuk mengeraskan timah (Rosa,F, 2016). Timah merupakan unsur kimia dengan nomor atom 50, nomor massa 118,69, sedangkan antimon memiliki nomor atom 51 dan nomor massa 121,76 .

\section{Talc}

Talc berfungsi untuk meningkatkan kekerasan cetakan karet (Setiawan, 2017). Dalam penelitian yang lain ditemukan bahwa laju kristalisasi dapat meningkat seiring dengan penambahan talc (Choi \& Kim, 2004).

\section{METODOLOGI PENELITIAN}

Penelitian dilakukan di laboratorium perhiasan Balai Besar Kerajinan dan Batik Yogyakarta (BBKB) dan Universitas Islam Indonesia (UII). Rancangan penelitian mengenai pembuatan gantungan kunci berbahan baku pewter dapat dilihat pada diagram alir di gambar 1 .

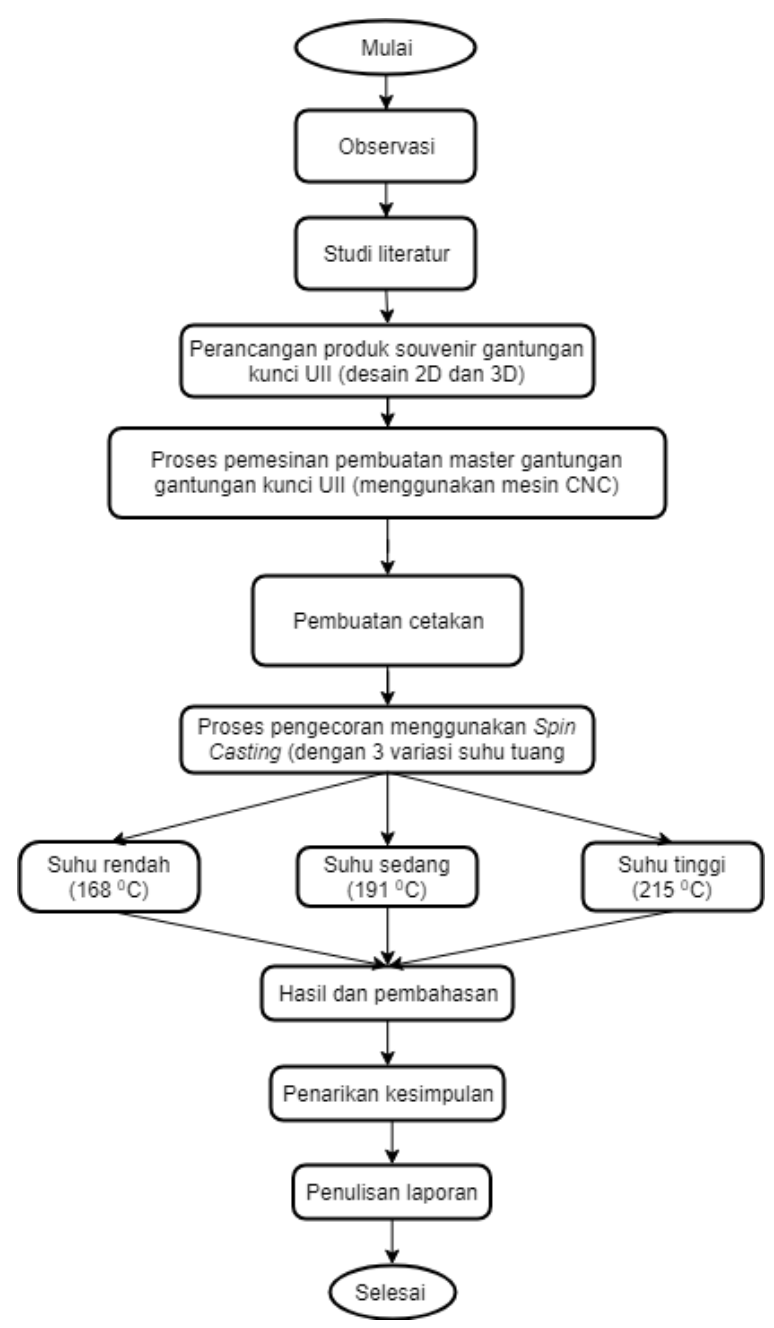

Gambar 1. Metodologi penelitian

\section{Alat Penelitian}




\section{Mesin CNC}

Mesin CNC yang digunakan adalah mesin CNC Roland EGX 600 yang berada di Laboratorium Sistem Manufaktur Teknik Mesin UII. Mesin CNC Roland EGX 600 digunakan untuk membuat master produk.

2. Timbangan Digital

Timbangan digital digunakan untuk mengukur massa produk dari hasil pengecoran.

3. Tabung Silinder

Digunakan untuk membuat cetakan produk pada proses spin casting.

4. Mesin Vacuum Degassing

Digunakan untuk mengeluarkan udara yang terjebak di RTV pada saat pembuatan cetakan. Mesin vacuum degassing ini berada di Balai Besar Kerajinan dan Batik Yogyakarta.

5. Pemanas (Kompor Gas LPG)

Digunakan sebagai pemanas atau meleburkan pewter

6. Termometer Laser

Digunakan untuk mengukur suhu tuang cairan logam (pewter)

\section{Mesin Spin Casting}

Digunakan untuk pengecoran produk. Mesin yang digunakan berada di Balai Besar Kerajinan dan Batik Yogyakarta.

8. Anyview Microscope

Digunakan untuk mengamati produk secara visual.

\section{Bahan}

1. Akrilik

Digunakan untuk membuat master produk

2. RTV 585 silicon rubber
Menggunakan silicon rubberjenis RTV 585 dari PT.Justus Kimiaraya Prancis

3. Katalis

Menggunakan bluesil catalyst 60R dari PT. Bluestar Silicones Shanghai Co., Ltd. Digunakan untuk mempercepat pengeringan RTV.

4. Talc

Digunakan sebagai campuran RTV pada cetakan spin casting yang berfungsi untuk menambah kekerasan pada cetakan karet. Talcyang digunakan adalah talc lioning powder.

\section{Pewter}

Menggunakan pewter dari PT. Indometal Asia sebagai bahan produk dengan komposisi $97 \%$ timah putih, $1 \%$ antimoni dan $2 \%$ tembaga yang dilebur sebelum dituang ke dalam mesin spin casting.

\section{Pembuatan Master}

Menentukan konsep desain master gantungan kunci

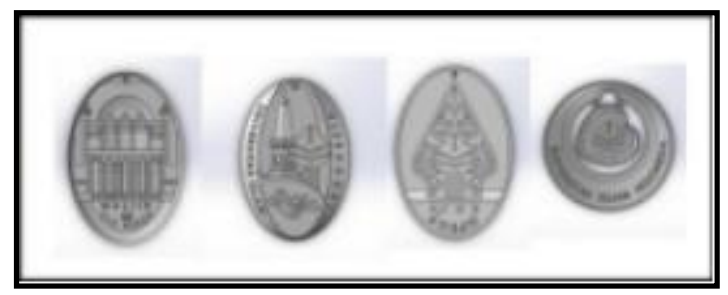

Gambar 2. Desain gantungan kunci terpilih

Konsep yang digunakan dalam pembuatan produk ialah membuat suvenir gantungan kunci dengan tema/ciri khas UII dan Yogyakarta. Dalam pembuatan desain master produk suvenir gantungan kunci menggunakan software CAD (Solidwork dan Artcam). Setelah membuat beberapa desain produk kemudian dipilih desain produk 
yang sesuai dengan kriteria yang diinginkan. Ada 4 buah desain yang dipilih dan sesuai dengan kriteria yang diinginkan.

\section{Penentuan material}

Penentuan material memiliki peranan tersendiri pada penelitian ini. Karena mempengaruhi biaya, kualitas dan baik buruknya produk yang akan dibuat.

a. Material master cetakan

Pada pembuatan master menggunakan material akrilik dengan ketebalan $4 \mathrm{~mm}$ (menyesuaikan dengan ketebalan master produk yang akan dibuat).

b. Material cetakan

Material yang digunakan untuk membuat cetakan adalah RTV 585 silicone rubber dengan bluesil catalyst 60R ditambah dengan powder penguat yaitu talc.

c. Material produk

Material yang digunakan dalam pembuatan produk adalah pewter.

\section{Proses pemesinan master}

Proses pemesinan dalam pembuatan master produk ialah menggunakan mesin CNC Roland EGX 600 dan material master produk suvenir gantungan kunci ini menggunakan bahan akrilik. Setiap pemesinan akan dilakukan dua tahapan yaitu pemesinan roughing kemudian dilanjutkan dengan finishing. Adapun tahapan dalam proses pemesinan master gantungan kunci UII menggunakan mesin CNC Roland EGX 600 sebagai berikut :

\section{a. Pemesinan roughing}

Roughing merupakan proses pemesinan yang masih kasar sehingga bentuk yang dihasilkan tidak halus.

\section{b. Pemesinan finishing}

Finishing merupakan proses pemesinan terakhir. Proses finishing lebih halus dibandingkan dengan roughing.

\section{Pembuatan cetakan karet spin casting}

Pembuatan cetakan menggunakan bahan RTV 585 silicon rubber. Penambahan catalyst digunakan untuk mempercepat pengeringan RTV ditambah dengan powder talc untuk meningkatkan atau memperbaiki sifat mekanik kekerasan dari RTV.

\section{Pembuatan produk}

Pembuatan produk menggunakan bahan pewter. Mesin spin casting dinyalakan pada kecepatan 300 rpm. Kecepatan putar ini diperoleh setelah melakukan percobaan ternyata pada kecepatan tersebut hasil cetakan dapat terisi sempurna. Setelah mesin spin casting berputar, bahan pewter dituangkan ke dalam cetakan dengan memanfaatkan gaya sentrifugal, bahan material masuk ke dalam rongga cetakan sehingga jadi produk yang sesuai dengan produk yang diinginkan. Kemudian dilakukan proses finishing.

\section{HASIL DAN PEMBAHASAN}

\section{Master suvenir gantungan kunci}

Master gantungan kunci dibuat menggunakan mesin Roland EGX 600 yang ada di laboratorium proses manufaktur Teknik Mesin, Fakultas Teknologi Industri, Universitas Islam Indonesia. Pembuatan master menggunakan bahan akrilik. Sedangkan untuk pahatnya menggunakan 
pahat flat conical yang bersudut 6 derajat dengan diameter collet $6 \mathrm{~mm}$.

Tabel 1. Parameter permesinan

\begin{tabular}{ccc}
\hline Parameter & Roughing & Finishing \\
\hline Stepover $(\mathrm{mm})$ & 0,3 & 0,08 \\
Stepdown $(\mathrm{mm})$ & 0,4 & 0,1 \\
Spindle speed & 10000 & 10000 \\
(rpm) & & \\
Feed rate (mm/sec) & 10 & 2 \\
Plunge rate & 4 & 3 \\
(mm/sec) & & \\
\hline
\end{tabular}

\section{Cetakan karet (Rubber Mold)}

Cetakan yang telah dibuat menggunakan bahan RTV 585 yang ditambah dengan talc dengan perbandingan $50: 1$ : 40 (50 gram untuk RTV, 1 gram untuk katalis dan 40 gram untuk talc). Gambar 3 menunjukan cetakan yang telah dibuat.
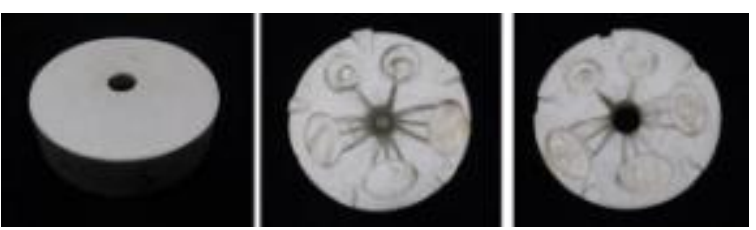

Gambar 3. Cetakan Karet

\section{Proses pengukuran suhu tuang}

Proses pengukuran suhu tuang dilakukkan sesaat sebelum cairan pewter dituangkan kedalam cetakan dengan menggunakan termometer laser. Termometer laser diarahkan ke cairan pewter yang akan dituang ke dalam cetakan karet silikon pada alat spin casting yang sedang bekerja. Pada penelitian ini proses pengukuran suhu tuang dilakukan dengan menggunakan tiga variasi suhu tuang yang disebut dengan suhu rendah, suhu sedang dan suhu tinggi. Rentang suhu titik leleh pewter $170-230{ }^{\circ} \mathrm{C}$ (Campbell, 2006).

a. Suhu rendah

Untuk suhu rendah berada di kisaran suhu $160^{\circ} \mathrm{C}-171^{\circ} \mathrm{C}$, seperti tampak pada gambar 4.

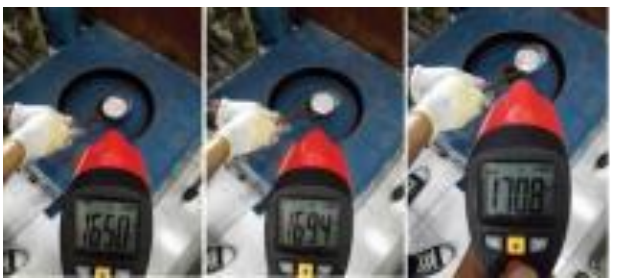

Gambar 4. Suhu rendah

b. Suhu sedang

Untuk suhu sedang berada di kisaran suhu $190^{\circ} \mathrm{C}-199^{\circ} \mathrm{C}$ seperti terlihat pada gambar 5 .

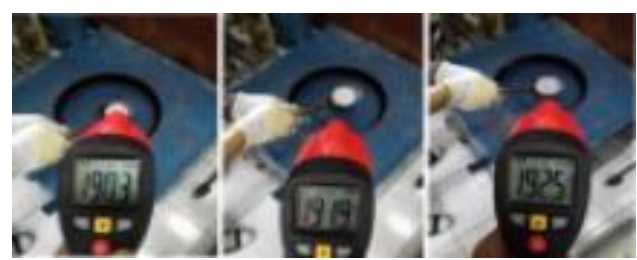

Gambar 5. Suhu sedang

c. Suhu tinggi

Untuk suhu tinggi berada di kisaran suhu $200^{\circ} \mathrm{C}-220^{\circ} \mathrm{C}$, dimana proses pengukuran suhu tuang dapat dilihat pada gambar 7 .

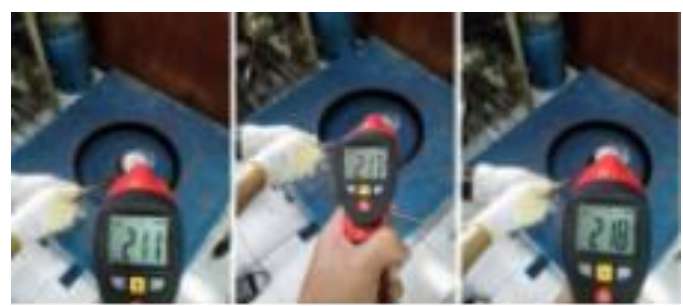

Gambar 7 . Suhu tinggi

\section{Hasil pengecoran spin casting}

Proses pengecoran produk suvenir gantungan kunci UII menggunakan mesin spin casting yang ada di BBKB. Dalam satu 
cetakan akan dihasilkan 5 (lima) produk gantungan pewter. Pada penelitian ini, setiap variasi suhu tuang dilakukan 3 (tiga) kali pengulangan. Hasil pengecoran dapat dilihat pada gambar 8,9 dan 10 di bawah ini.

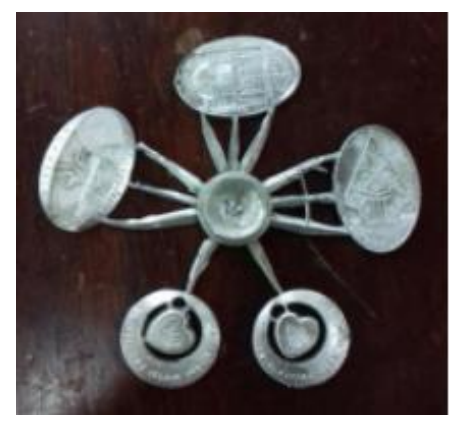

Gambar 8. Hasil pengecoran suhu rendah

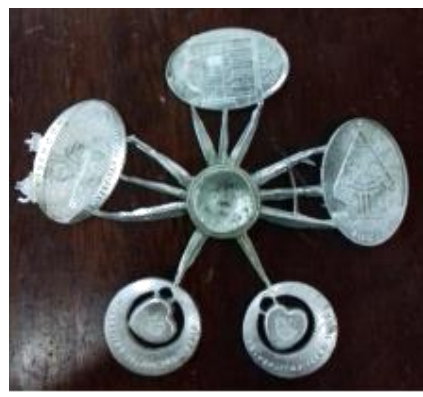

Gambar 9. Hasil pengecoran suhu sedang

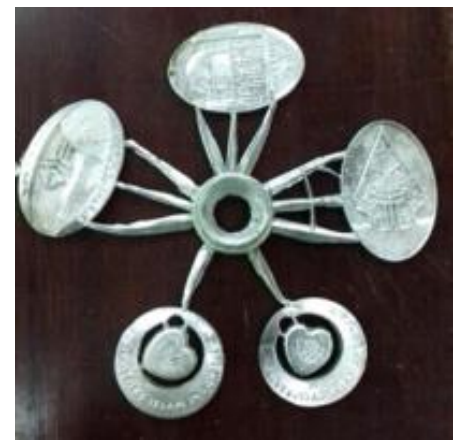

Gambar 10. Hasil pengecoran suhu tinggi

\section{Analisa hasil pengecoran}

Pada proses pengecoran spin casting dengan cetakan yang telah dibuat menghasilkan 5 produk untuk sekali tuang. Tetapi dalam pengamatan hasil pengecoran ini mengambil 3 sampel dari setiap variasi suhu yaitu desain 1, 2 dan 3 . Jadi secara keseluruhan terdapat 9 sampel untuk diamati. Untuk proses yang dilakukan dalam mengamati hasil pengecoran dari 3 variasi suhu ialah dengan uji struktur makro menggunakan alat Anyview Microscope, dimana dari masing-masing desain diambil tiga titik untuk dilakukan pengamatan dan perbandingan antara suhu satu dengan yang lainnya. Berikut ini adalah hasil pengamatan uji struktur makro dengan menggunakan Anyview Microscope.

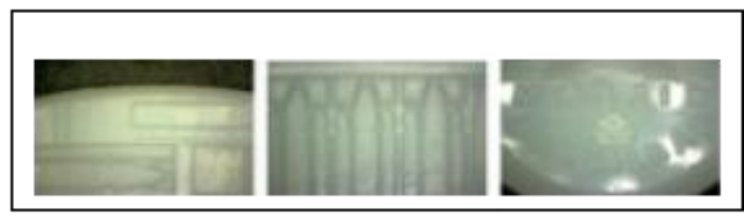

Gambar 11. Detail pada master desain 1

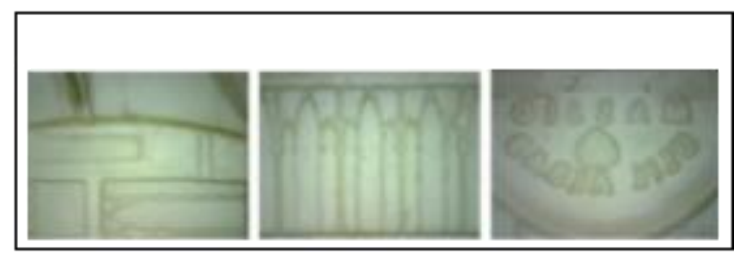

Gambar 12. Detail pada cetakan desain 1

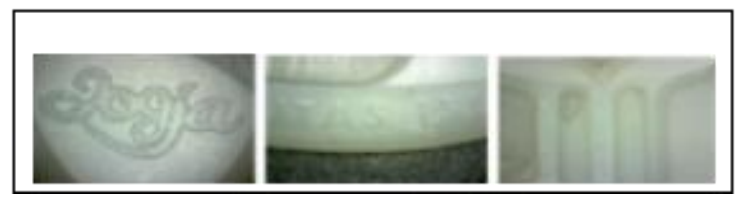

Gambar 13. Detail pada master desain 2

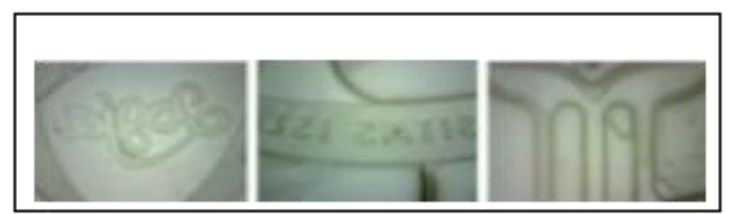

Gambar 14. Detail pada cetakan desain 2 
Tabel 2. Analisa hasil pengecoran pada desain 1 pengamatan uji struktur makro

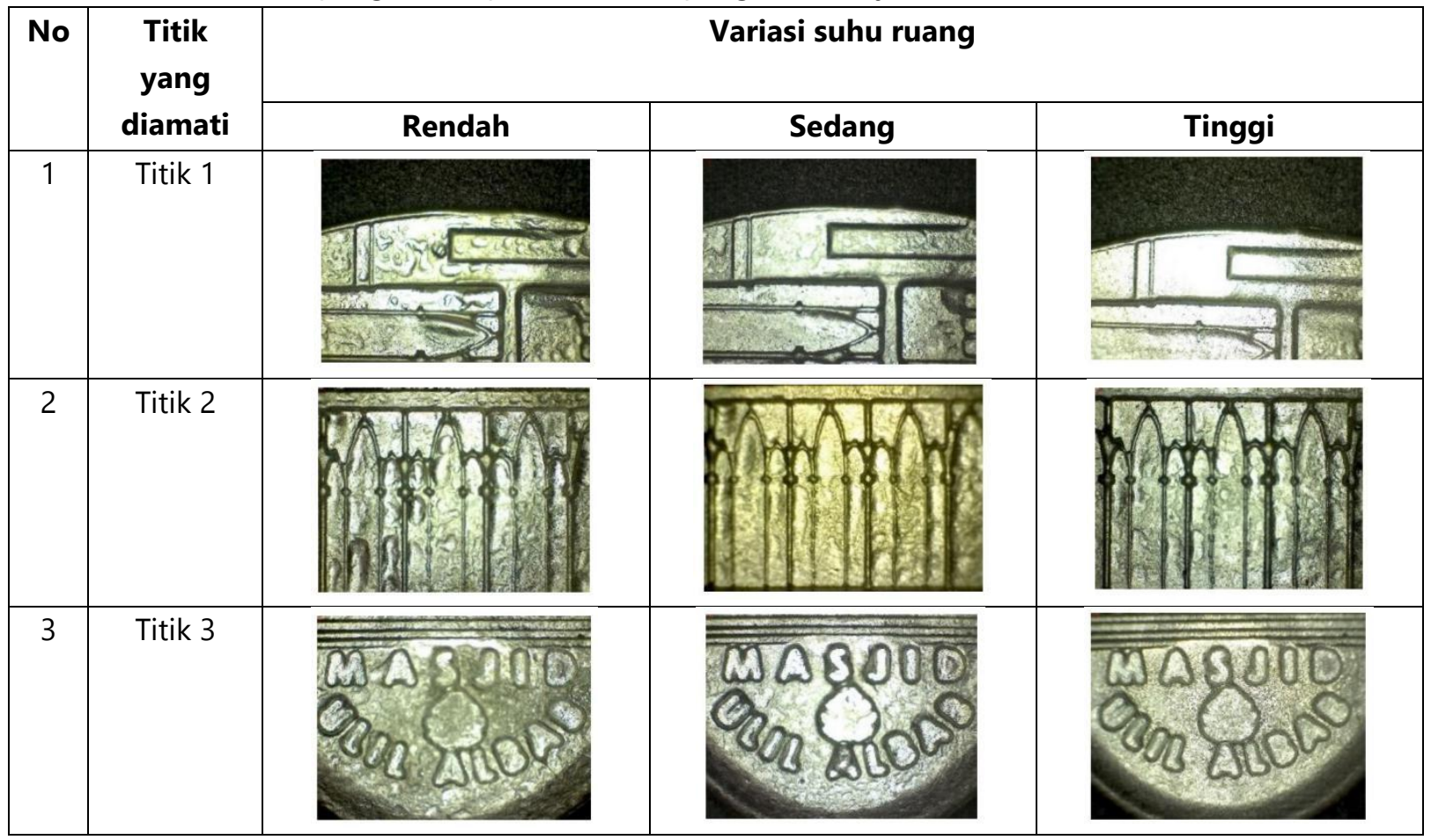

Tabel 3. Analisa hasil pengecoran pada desain 2 pengamatan uji struktur makro

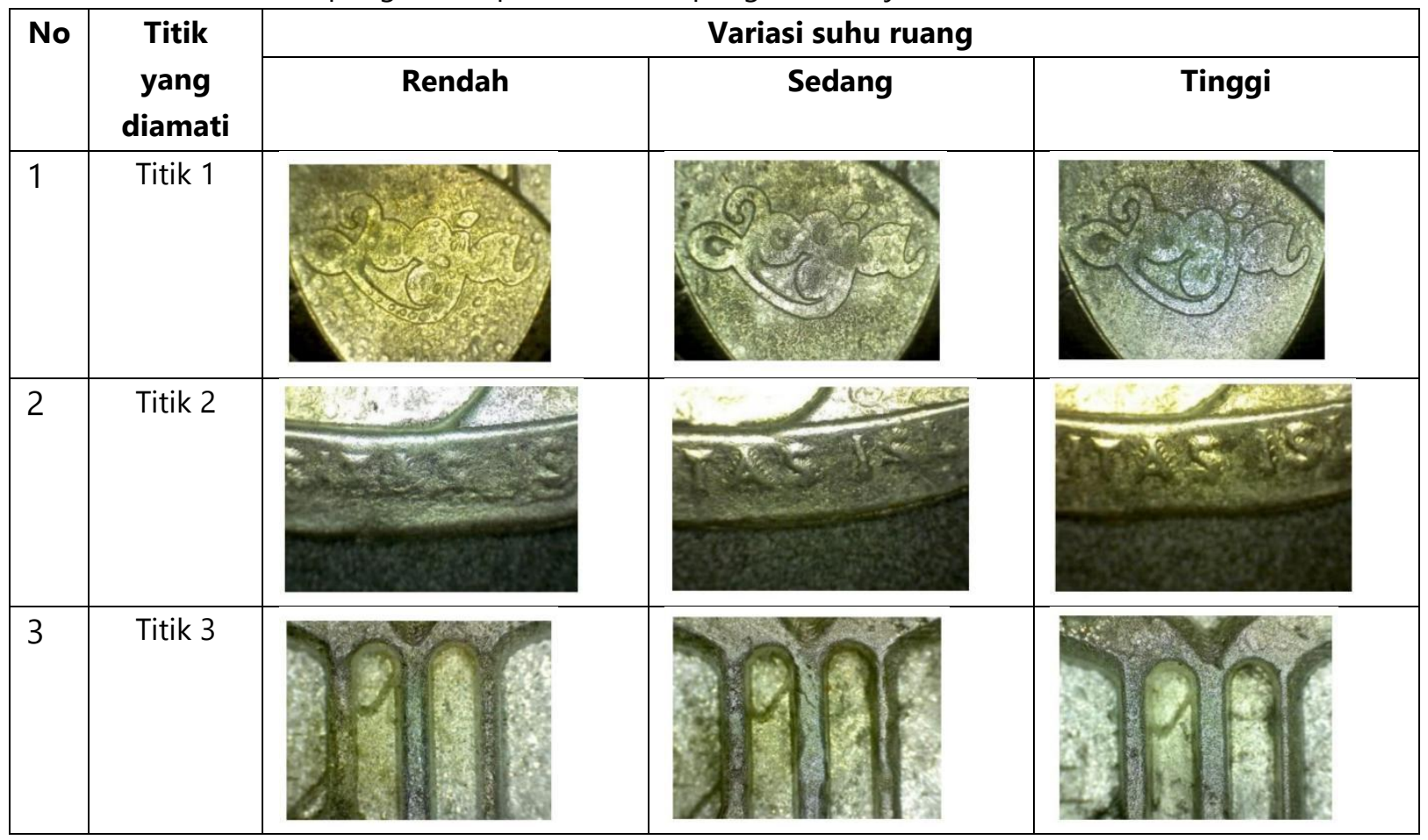


Tabel 4. Analisa hasil pengecoran pada desain 3 dengan pengamatan uji struktur makro

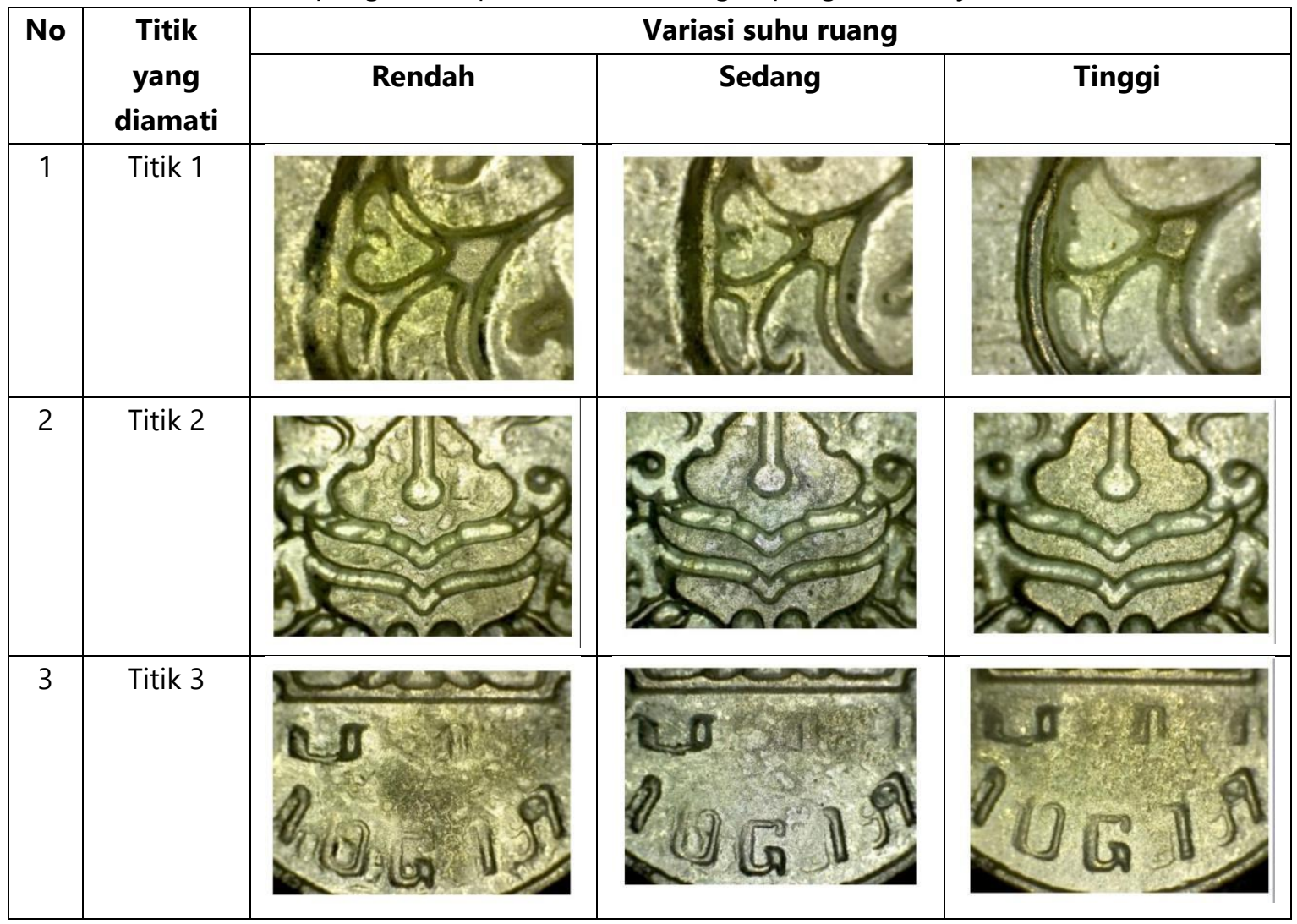

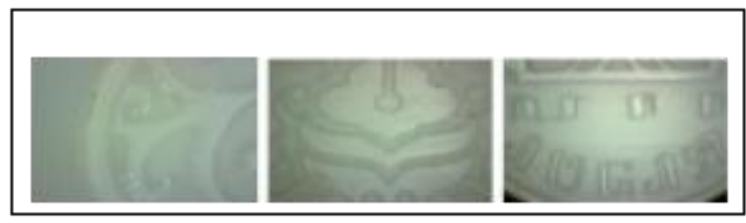

Gambar 15. Detail pada master desain 3

Hasil dari pengamatan produk pengecoran menunjukan bahwa variasi suhu tuang yang tinggi lebih mampu mengisi celah kecil pada cetakan, hal ini dikarenakan pada variasi suhu tuang tinggi viskositas cairan pewter lebih rendah sehingga profil produk yang dihasilkan lebih terlihat dan lebih tajam serta mendekati hasil yang sempurna apabila dibandingkan dengan variasi suhu rendah dan sedang. Permukaan produk pengecoran variasi suhu tinggi juga relatif lebih halus jika dibandingkan dengan variasi suhu rendah dan sedang.

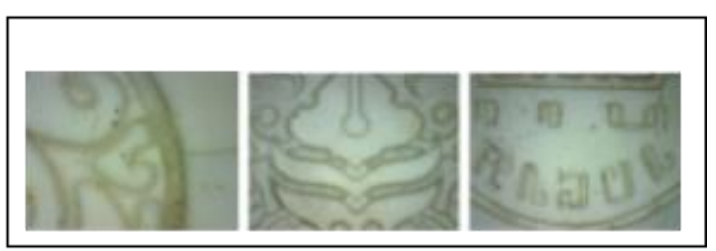

Gambar 16. Detail pada cetakan desain 3

\section{Hasil pengukuran massa}

Pengukuran massa produk dilakukan dengan menggunakan timbangan digital. Sebelum melakukan pengukuran massa produk hasil pengecoran dibersihkan terlebih dahulu dari bekas jalur 
pengecoran dan bek as cairan logam yang mengalir pada celah cetakan.

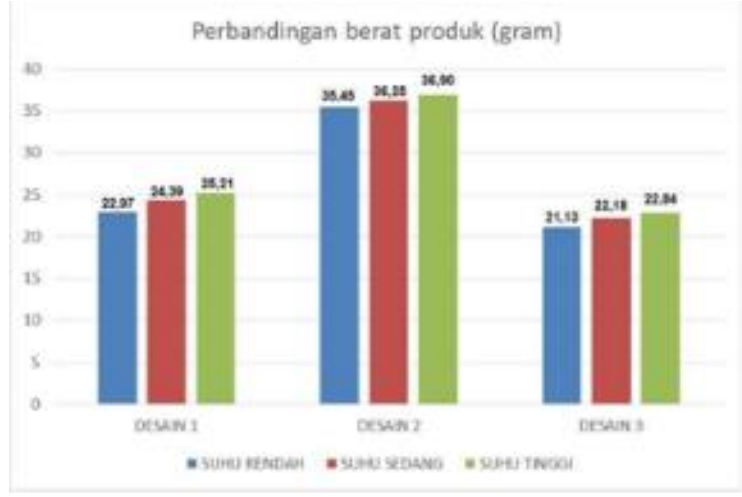

Gambar 17. Grafik hasil pengukuran massa

Dari pengukuran massa produk pengecoran menunjukan bahwa variasi suhu tuang paling tinggi mempunyai massa produk paling tinggi apabila dibandingkan dengan variasi suhu rendah dan sedang.

\section{Analisa Visual Hasil Patahan}

Analisa visual hasil patahan dilakukan dengan uji struktur makro pada permukaan patahan dengan menggunakan alat Anyview Microscope. Untuk hasil dari analisa visual dari permukaan patahan tersebut dapat dilihat pada gambar 18 .

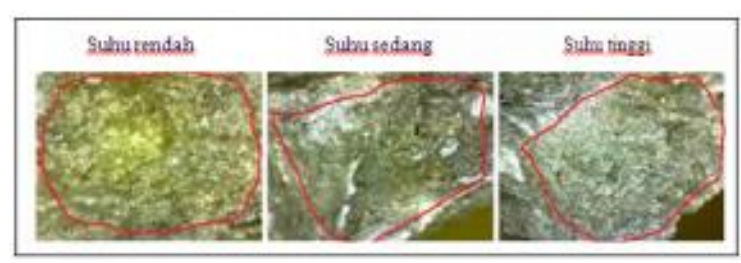

Gambar 18. Hasil patahan

Dari hasil pengamatan tersebut dapat dilihat bahwa variasi suhu tinggi lebih terisi dan lebih homogen, hal ini terbukti pada hasil pengukuran massa bahwa produk hasil cor dengan variasi suhu tinggi adalah yang paling berat. Kemudian arah serat patahan lebih seragam dan serat patahannya pun lebih panjang hal tersebut menunjukan bahwa hasil pengecoran pada suhu tinggi lebih ulet apabila dibandingkan dengan variasi suhu rendah dan sedang.

\section{Pembahasan}

Dari hasil pengamatan produk pengecoran maupun pengamatan visual menunjukan bahwa variasi suhu cairan logam paling tinggi adalah yang mampu mengisi relief-relief yang sempit pada cetakan sehingga mampu menghasilkan produk yang mendekati sempurna seperti yang diinginkan. Namun, untuk produk yang reliefnya simpel dan tidak sempit atau tidak tipis maka dengan menggunakan variasi suhu sedang pun bisa digunakan.

Saat ini pengrajin pewter membuat kerajinan dengan menggunakan sistem cor tuang sehingga hasil cetakan kurang padat (tingkat porositas tinggi).

\section{Kesimpulan}

Dari penelitian yang dilakukan, dapat ditarik kesimpulan bahwa variasi suhu tuang berpengaruh terhadap kualitas produk souvenir gantungan kunci pewter, dimana dari tiga variasi suhu tuang yang digunakan maka suhu tinggi hasil cetakannya paling bagus dan tajam serta mampu mengisi bagian-bagian relief yang tipis. Berdasarkan perbandingan beratnya, hasil produk suhu tinggi adalah yang paling berat. Hal ini dikarenakan cairan logam variasi suhu tinggi lebih mampu mengisi relief yang tipis. 
Untuk membuat gantungan kunci yang tidak terlalu rumit, maka suhu sedang dan bahkan suhu rendahpun masih bisa digunakan. Hal ini sangat bergantung terhadap kualitas produk dan desain yang dikehendaki.

\section{Saran}

Perlu dilakukan penelitian mengenai jarak celah optimum yang bisa dibuat pada cetakan spin casting. Juga perlu dilakukan kajian mengenai hubungan antara ketebalan master produk dengan kecepatan putar mesin spin casting.

\section{KONTRIBUSI PENULIS}

Penulis pertama kontributor utama dalam penulisan Pengaruh Suhu Tuang Pada Kualitas Gantungan Kunci Berbahan Baku Pewter Dengan Metode Spin Casting ini.

\section{UCAPAN TERIMAKASIH}

Terima kasih kami ucapkan untuk Kepala Balai Besar Kerajinan dan Batik beserta staff khususnya di lab Perhiasan, Bapak ketua jurusan Teknik Mesin UII beserta staff dan pihak-pihak yang turut membantu penelitian ini.

\section{DAFTAR PUSTAKA}

Atha Illah, M., \& Ardhyananta, H. (2013). Pengaruh Jenis Katalis terhadap Kekuatan Tarik dan Stabilitas Termal Polidimetilsiloksan (PDMS) untuk Lapisan Pelindung Baja AISI 1050. Jurnal Teknik POMITS, 2(1), 41-44.

Balingit, W. H., \& Maglaya, A. B. (2013). Numerical Optimization of the Spin Casting Process Parameters. World Applied Sciences Juournals, 21(8), 1106-1112. https://doi.org/10.5829/idosi.wasj.2013.21. 8.3293

Buontempo, R. C., Dellallibera, A. A., Costa, E. C. M., Pissolato, J., De Mello, D. R., \& Mei, L. H. I. (2016). Electrical assessment of commercial 6.0-kV HTV silicone rubber for power insulation. Measurement: Journal of the International Measurement Confederation, 89, 114-119. https://doi.org/10.1016/j.measurement.201 6.04 .008

Campbell, Gordon (2006), The Grove encyclopedia of decorative arts (illustrated ed.), Oxford University Press, ISBN 978-019-518948-3

Choi, W. J., \& Kim, S. C. (2004). Effects of talc orientation and non-isothermal crystallization rate on crystal orientation of polypropylene in injection-molded polypropylene/ethylene- propylene rubber/talc blends. Polymer, 45(7), 23932401.

https://doi.org/10.1016/j.polymer.2004.01. 058

Danglad-Flores, J., Eickelmann, S., \& Riegler, H. (2018). Deposition of polymer films by spin casting: A quantitative analysis. Chemical Engineering Science, 179, 257-264. https://doi.org/10.1016/j.ces.2018.01.012

Karpitschka, S., Weber, C. M., \& Riegler, H. (2015). Spin casting of dilute solutions: Vertical composition profile during hydrodynamic-evaporative film thinning. Chemical Engineering Science, 129, 243248.

https://doi.org/10.1016/j.ces.2015.01.028

Kumar, V., Lee, D. J., \& Lee, J. Y. (2016). Studies of RTV silicone rubber nanocomposites based on graphitic nanofillers. Polymer Testing, 56, 369-378. https://doi.org/10.1016/j.polymertesting.20 16.11 .004

Puji Widi Rahayu. (2013). Kerajinan Logam Timah "PEWTER" Muntok Kabupaten Bangka Barat Provinsi Bangka Belitung. Yogyakarta.

Rosa,F (2016). Analisa Lanjut Perubahan Sifat Mekanik Bahan Pewter Dengan Reduksi 50 \% Pada Proses Pengerolan Bahan. Sintek, 10(1), 17-22. 
Setiawan, J. (2010). Penelitian Waktu Optimal Pengeluaran Gas pada Pembuatan Cetakan Karet dengan RTV Silicone Rubber. Dinamika Kerajinan Dan Batik: Majalah Ilmiah.

Setiawan, J. (2017). Pengaruh Penambahan Talc Terhadap Peningkatan Nilai Kekerasan Cetakan RTV Silicone Rubber Pada Proses Spin Casting, 34(1), 1-10.

Zheng, C., Wang, G., Chu, Y., Xu, Y., Qiu, M., \& $X u, M .(2016)$. RTV silicone rubber surface modification for cell biocompatibility by negative-ion implantation. Nuclear Instruments and Methods in Physics Research, Section B: Beam Interactions with Materials and Atoms, 370, 73-78. https://doi.org/10.1016/j.nimb.2016.01.01 4 
IlKh Dinamika Kerajinan dan Batik: Majalah Ilmiah. Vol. 36 No. 1, Juni 2019 Hal. 47 - 60 